\title{
Exploring differences in communication behaviors between organic and conventional farmers
}

\author{
Fallys Masambuka-Kanchewa, ${ }^{\text {* }}$ Joy Rumble, ${ }^{\mathrm{b}}$ and Emily B. Buck ${ }^{\mathrm{c}}$ \\ The Ohio State University
}

Submitted May 29, 2020 / Revised July 15, September 17, and November 4, 2020, and January 19

and February 21, 2021 / Accepted February 22, 2021 / Published online July 10, 2021

Citation: Masambuka-Kanchewa, F., Rumble, J., \& Buck, E. B. (2021). Exploring differences in communication behaviors between organic and conventional farmers. Journal of Agriculture, Food Systems, and Community Development, 10(3), 205-219. https://doi.org/10.5304/jafscd.2021.103.018

Copyright (C) 2021 by the Authors. Published by the Lyson Center for Civic Agriculture and Food Systems. Open access under CC-BY license.

\begin{abstract}
This exploratory qualitative study sought to gain initial insights into how farmers involved in different production practices communicate with consumers. A thematic analysis of in-depth interviews conducted with eight organic and 12 conventional farmers in Ohio indicated that organic farmers are proactive in communicating with the public about their production practices, unlike conventional farmers, who focus on improving productivity. Furthermore, the organic farmers reported using different communication channels such as Facebook, flyers, and YouTube

\footnotetext{
a * Fallys Masambuka-Kanchewa, Ph.D. candidate, The Ohio State University.

Masambuka-Kanchewa, Ph.D., is now a postdoctoral research associate, Agricultural Leadership, Education and Communication, The University of Georgia; Four Towers, 405 College Station Road, Suite, 209; Athens, Georgia 30602 USA; +1-614-551-8580; Fallys.masambuka@,uga.edu

b Joy Rumble, Ph.D, Assistant Professor, Agricultural Communication Education and Leadership, The Ohio State University; Rumble.6@osu.edu

c Emily B. Buck, Ph.D., Professor, Agricultural Communication Education and Leadership, The Ohio State University; Buck.210@,osu.edu
}

when communicating with consumers, while conventional farmers reported being busy working on their farms and not having time to communicate with consumers. Organic farmers' involvement in communication activities with the public about their production practices and products was reported to stem from their beliefs and values toward sustainable farming practices and environmental conservation. Furthermore, unlike conventional farmers, most organic farmers sold their produce directly to consumers, and as such, used communication as a marketing tool. The active involvement of organic farmers in communicating with consumers may be attributable in part to increased media coverage about the benefits of organic farming practices. On the other hand, limited involvement of conventional farmers in communicating with the public may be partially attributable to limited media coverage about the benefits of conventional farming. Therefore, to ensure that consumers make informed decisions,

\section{Author Note}

This paper was part of a pilot test for the first author's dissertation. Parts of the materials from this paper were presented as poster presentations at two annual conferences in 2019 and 2020. 
there is a need to start developing standalone communication organizations and interventions committed to providing unbiased information about the benefits and disadvantages of the different farming practices.

\section{Keywords}

Negative Perceptions about Agriculture, Farmers, Communication, Mainstream Media, Conventional Farming, Organic Farming, Production Practices, Proactive Versus Reactive

\section{Introduction}

As early as 1940, scientists recognized the need for investing in the development of improved technologies as essential for increasing agricultural productivity to feed the world (Patel, 2013). These developments led to the introduction of farming practices that today we call conventional farming. The development of new food production technologies has led to changes in agriculture, differentiating farmers based on their production practices (Cranfield et al., 2010). The differences in production practices have led to a growing debate among the public as to which farming practices are best, with the majority preferring organically produced foods (Abrams et al., 2010).

Conventional farming involves "the use of seeds that have been genetically altered using a variety of traditional breeding methods, excluding biotechnology, and are not certified as organic" (USDA, 2015b, p. 1). Thus conventional farming is associated with high productivity and characterized by the increased use of synthetic inorganic fertilizers, herbicides, and pesticides (Kirchmann, 2019; Mzoughi, 2011). Despite the high productivity, the use of chemical fertilizers and pesticides has been associated with negative environmental and health impacts due to increased emission of green-house gasses (Kirchmann, 2019).

In response to these negative impacts, organic farming was introduced as one way of conserving the environment and ensuring production of highquality foods in a sustainable way (Barton, 2018). Organic farming, among other techniques, has been known to contribute to higher food quality and reduction in greenhouse emissions (Kirchmann, 2019). However, no clear or standard definition of organic farming exists, as it differs depending on regulations and consumers' perceptions (Seufert et al., 2017). For example, the USDA (2015a) defined certified organic farming for certification purposes as "farming practices [that] exclude the use of irradiation, sewage sludge, synthetic fertilizers, synthetic pesticides, and biotechnology" (p. 1). On the other hand, organic farming is also defined as a cultural movement aimed at reducing the need for use of chemical fertilizers and pesticides in crop production (Barton, 2018).

The increased chemical and pesticide use associated with conventional farming has led to consumers' concerns about the safety of conventionally produced food products. In response, there has been increased media coverage about the benefits of organic farming (Cahill et al., 2010). However, public perceptions of organically produced foods as healthy, tasty, and safe have been attributed to consumers' attitudes, and not to actual differences in the foods based on production practices ( $\mathrm{Da}$ Cunha et al., 2019; Nadricka et al., 2020; Xie et al., 2015). The mainstream media has been criticized for framing organically produced food as "ethical" and "healthy" (Abrams et al., 2010; Cahill et al., 2010). Several studies conducted in the U.S. indicate that the mainstream media contributes to negative perceptions about conventional agriculture among consumers (Baker et al., 2011; Charanza \& Naile, 2012; McCluskey et al., 2016; Sellnow \& Sellnow, 2014; Specht \& Beam, 2015). For example, media coverage of genetically modified organisms (GMOs) has been associated with negative perceptions about GMOs among consumers (Marques et al., 2015; McCluskey et al., 2016).

In response, agricultural communication has been used as a public relations tool (Irani \& Doerfert, 2013). Agricultural communication involves the delivery of information to the public and various stakeholders involved in the agricultural industry using different communication channels. It plays a crucial role in ensuring that the public has access to reliable and clear information to guide them in making informed decisions (Gottschalk \& Leistner, 2013).

Since its establishment as a field, agricultural communication in the United States has gone through a lot of changes_-from disseminating 
information to farmers about improved farming practices to disseminating scientific information to the public, advocacy, and public relations (Irani \& Doerfert, 2013). Recently, agricultural communication research and interventions in the U.S. have focused on the impact of the media on the creation of negative perceptions about agriculture among consumers (Baker et al., 2011; Charanza \& Naile, 2012; Kurtzo et al., 2016; Meyers et al., 2011; McCluskey et al., 2016; McKendree et al., 2014; Sellnow \& Sellnow, 2014; Specht \& Beam, 2015). Unlike in the past, when information was disseminated from experts to farmers, improved technological advancements in communication have led to the presence of a myriad of information sources, including farmers. Now, farmers are not merely passive receivers of information but information generators and sharers as well (Prokopy et al., 2017). Therefore, realizing that farmers involved in different and contradictory farming practices are also considered as knowledge generators and have potential to use various communication channels to communicate with consumers, there are questions regarding the impact of their communication behaviors on consumers' perceptions of agriculture.

\section{Theoretical Framework}

Communication research "involves understanding how people behave in creating, exchanging, and interpreting messages" (Littlejohn \& Foss, 2010, p. 9). Several theories are used in understanding this, such as interpersonal communication and relations theories that describe processes by which people exchange messages and the associated effects on relationship development (Dainton, 2010). In an attempt to establish relationships, farmers communicate with each other as well as the public. The messages exchanged during the communication process influence relationship development. Therefore, in this study, some of the concepts of theory of planned behavior (TPB) and attribution theory were used to explore farmers' communication behaviors and the associated relationships.

The theory of planned behavior (Ajzen, 1985) describes various factors that influence an individual's decision-making process to act or behave in a certain way (Conner \& Armitage, 1998). It empha- sizes the role of perceived control as well as normative beliefs in influencing behavior (Ajzen, 1985, 1991). The theory indicates it is easier for a person to portray a certain behavior when they feel they have control over resources or opportunities necessary for them to behave in a particular manner (Ajzen, 1991). In addition, it describes the role of beliefs and values in influencing attitudes regarding certain behaviors (Conner \& Armitage, 1998). The theory indicates that believing a given behavior will yield an acceptable outcome contributes to the development of a positive attitude toward that behavior.

Values describe an individual's attachment of judgment to an object or behavior as being either good or bad and right or wrong (Gasson, 1973). They play a critical role in decision-making as they serve as guidelines for acceptable or unacceptable behavior (Gasson, 1973; ÖhlméYr et al., 1998). Differences in production practices among farmers, which stem from differences in experience, size of land, potential markets, membership in groups or organizations, and beliefs and values toward agriculture have the potential to contribute to differences in farmers' communication behaviors (Agunga, 1995; Alexopoulos et al., 2010; Bravo-Monroy et al., 2016).

Farmers, like consumers, have different reasons for engaging in certain systems when producing agricultural products (Bravo-Monroy et al., 2016; Darnhofer et al., 2005; Torjusen et al., 2001). For example, Mzoughi (2011) reported that among other concerns, moral and social concerns were the drivers for choosing to engage in organic farming, while economic concerns were among factors for not engaging in organic farming. Farmers who are in favor of organically produced foods have been known to also prioritize sustainable farming practices and value environmental conservation (BravoMonroy at al., 2016; Torjusen et al., 2001). Additionally, Spooner, Schuppli, and Fraser (2014) suggest a link between farmers who value animal welfare and sustainable and organic farming practices. These values may influence organic farmers' communication behaviors and increase the likelihood of positive relationships with consumers, while encouraging negative perceptions toward conventional production (Coombs, 2007). 
Despite the impact of beliefs and values in influencing farmers' choice of farming practices, no studies have been conducted aimed at exploring how beliefs and values influence farmers' communication behaviors with consumers. Moreover, the theory has mainly been applied in quantitative research studies (Stone et al., 1999), where the closed-ended questions used limit respondents' chance to express their views freely. Therefore, in order to capture participants' opinions, a qualitative approach has been employed in this research.

Attribution theory has also been used in this study. The theory looks at the tendency and presence of critical analytical skills among people to explain causes of events or behavior (Heider, 1958). The theory provides explanations of factors that influence people's behavior and judgments (Fatemi \& Asghari, 2012). Such explanations are based on the tendency by people and among people to attach outcomes of events to one another (Weiner, 1986). Several studies have reported mainstream media as being responsible for perpetuating negative perceptions about agriculture in general among consumers (Charanza \& Naile, 2012; Sellnow \& Sellnow, 2014; Specht \& Beam, 2015). Moreover, there has been growing media coverage regarding the debate between organic and conventional farming (Cleveland et al,, 2015; Feldmann \& Hamm, 2015; Harper \& Makatouni, 2002; Hughner et al., 2007; Krystallis \& Chryssohoidis, 2005; McCluskey et al., 2016). Furthermore, there has been more coverage and positive frames being created about organic farming as opposed to conventional farming (Abrams, et al., 2010; Cahill et al., 2010). The availability of food produced through different production practices provides mainstream media with an opportunity to select messages that resonate with their audience (Funk \& McCombs, 2017).

In addition, the presence of organic advocacy groups has contributed to increased media coverage of organic farming as the best farming practice, further exacerbating negative consumer perceptions of conventional agriculture (Charanza \& Naile, 2012; Coombs, 2007; Sellnow \& Sellnow, 2014). Research using attribution theory has focused on understanding consumers' abilities to critically analyze the information contained in the message (Chakraborty \& Bhat, 2018; Legendre \& Coderre, 2018). However, such analysis has been based on understanding consumers' internal or external attributes associated with the message and how such attributes influence their receptivity of the message (Laczniak et al., 2001).

The absence of research aimed at assessing factors influencing farmers' involvement in communication stems largely from an emphasis on the use of agricultural communication as a reactive tool for mitigating negative perceptions about agriculture among the public (Kurtzo et al., 2016). Since the inception of agricultural communication, there has been emphasis on using it as a tool for educating the public and farmers. However, agricultural communication can be used as a science for understanding people's behaviors. Moreover, the role of farmers in communication has often been viewed as that of receivers of agricultural information. Because of this, research on farmers' communication behaviors has focused on understanding farmers choice and use of communication channels for accessing information (Arbuckle et al, 2015; Mase \& Prokopy, 2014; Varble et al., 2016). A gap remains in explaining farmers' feelings, values, and intentions that they are likely to contribute to their choices of production practice and communication behaviors.

Similar to consumers who have attributes that determine their consumption behaviors and food choices, farmers have attributes that influence their production decisions (McGuire et al., 2013). In the mid-1990s, Agunga (1995) reported about the potential for differences in farmers' attributes to contribute to the differences in production practices used, and, hence, differences in their communication behaviors. However, at that time, the differences in farming practices were not as much a cause for debate as they are currently. Therefore, it is important to explore how differences in farmers' attributes influence their communication behaviors and how that affects the type of information available to consumers.

\section{Purpose and Research Questions}

This study sought to explore how farmers involved in various production practices communicate with consumers. The following questions served as a 
guide for the research: How do farmers involved in different production practices identify themselves? Are there differences in communication behaviors among and between farmers following different production practices? How might differences in communication behaviors between and among conventional and organic farmers contribute toward negative perceptions about agriculture?

\section{Methods}

The study employed a qualitative research design, as it "focuses on the meanings, traits and defining characteristics of events, people, interactions, settings/cultures and experience" (Richard, 2013, p. 38). Data were collected in January 2018 during the Young Farmers conference after getting approval from Ohio State Institutional Review Board. The conference drew all farmers regardless of their farming practices. Thus both organic and conventional farmers were recruited for the study. No deliberate efforts were made to recruit a specific group of farmers based on their production practices.

Using a convenience sample, 20 farmers (12 conventional and eight organic farmers) who were attendees at the Young Farmers conference that was held in Ohio in January 2018 were recruited and involved in key informant interviews. An interview guide was developed based on the results of a content analysis of communication artifacts that were created between 2010 and 2016 (Masambuka et al., 2018). It contained questions that assessed farmers' use of different communication channels when accessing or sharing agricultural information. A question regarding participants' connection to agriculture was added to the guide during the data collection process when the researchers realized there were differences in participants' communication behaviors based on their farming practices (Galleta, 2003). The question focused on establishing how the participants identified themselves in relation to their farming practices. The interview guide was reviewed by a panel of experts composed of two communication professors, one agricultural extension educator, and one qualitative data research expert.

The conference ran for two days; during registration on the first day, the researchers approached attendees and asked if they were willing to take part in the study. On the second day, only participants who attended sessions focused on communicating with the public were approached (Paul et al., 2013). The researchers attended all of the sessions on communication. Each interview lasted for a minimum of 30 minutes and was recorded with an audio recorder after obtaining consent. Before analyzing the data, member checking was conducted with selected participants who were provided with the transcribed data through email (Harvey, 2015). Member checking is one of the quality control processes used in qualitative research where participants are provided with an opportunity to review their statements to ensure that the researcher captured them accurately (Harper \& Cole, 2012),

\section{Data Analysis}

Data were analyzed using NVivo Pro, a data analysis software where themes and subthemes were generated. Case-oriented analysis was employed when analyzing the data (Della Porta, 2008). This involves analyzing the number of themes emerging from the data collected from a specific participant as opposed to analyzing data from various participants while searching for specific variables (Ragin \& Schneider, 2011). In addition, a similar analysis method to Valli and Buese (2007) was used, where data were analyzed in phases. However, unlike Valli and Buese, who followed four phases, this study used only three. The first phase involved identification of farming practices, where farmers were categorized as organic farmers, conventional farmers, or both. Based on this categorization, each farmer's codes were created pertaining to their values regarding the farming practice in which they were involved, communication behaviors with other farmers and consumers, and motivations for engaging in communication behaviors. Following the preliminary data analysis, another researcher who was not involved in the data-collection process compared the themes and subthemes with the transcribed data and identified common themes that informed the findings (Flick, 2002). Saturation was established when there were no new themes emerging from the data (Urquhart, 2013). Only themes that were present for both categories of 
farmers (conventional and organic) were used to inform the results of the study.

\section{Reflexivity Statement}

The primary researcher was an international doctoral student at The Ohio State University at the time of data collection. The researcher recognized she was perceived as not being knowledgeable about the participants' lived experiences or American agriculture in general because she was an outsider, which may have contributed to the openness of the participants to share more information than they may have otherwise (Dwyer \& Buckle, 2009). Moreover, being an outsider allowed the researcher to ask more questions and seek elaboration on issues that she did not understand because of cultural differences as well as lack of familiarity with the American agricultural system (Couture et al., 2012). However, a second researcher assisted in unveiling some of the issues or areas where the primary researcher may not have understood or captured the issues properly since English was their second language. In cases where the second researcher noticed that something did not make sense or was not clear, the researchers emailed the participants to ensure that the necessary changes were made.

\section{Results}

\section{Farmers' Identification}

Differences were observed regarding how farmers identified themselves based on their production practices. All of the organic farmers (five men and three women) identified themselves by indicating their production practices. One of the middle-aged, male, organic farmers stated,

Oh, well my wife and I live on a 400-acre farm. It is owned by her parents and we are looking to start our own type of business model with agriculture and hopefully looking into what most people wouldn't say the regular route which is open field grass fed. Trying to get out from the cages and to treat animals as they should be treated and produce for the consumers in a way that they want food to be produced.
However, all of the conventional farmers (11 men and one woman) did not identify themselves based on the production practices they followed but rather by what they farmed. For example, a middle-aged, conventional farmer from northern Ohio stated, "I farm corn, soybeans, wheat crops, and also raise livestock cattle and several hundred chickens, we produce eggs." This was echoed by another conventional, female farmer from southern Ohio who stated,

So, my husband and I we have a beef cattle operation in southern Ohio, in Highland County, ... we raise beef cattle, commercial, and we do a little bit of like club calf, show calves, and then we raise hay on our farm. So, we have a 94-acre farm there. We do hay just for our own production.

Even though the conventional farmers did not identify themselves based on their production practices, they described organic farmers as being inexperienced, as stated by one of the male conventional farmers from central Ohio:

Some organic people maybe weren't raised on the farm. They've started later on in life and they think well we can do it better than these guys. We've read all the books. We gonna do it this way. And let alone they don't wanna talk to us because they are in the path. That's OK. Other people, they have very few acres and they can get more money per acre out of an organic crop. It takes more work but there is more money in revenue there per acre instead of mass acres so they are trying to do more with less and get more for their product, which is great so there's all different aspects of it.

On the other hand, the organic farmers perceived themselves as being stewards of the environment and producers of products that are healthy, as exemplified in the following quotation from a middle-aged, male farmer from central Ohio: "I have to maintain absolutely 100 percent integrity for my products. ... I will never go beyond what my land can sustain." This sentiment 
was echoed by another middle-aged, organic, male farmer from eastern Ohio:

I will never go beyond what my land can sustain and go beyond questioning the integrity of my product. So, I will never outgrow myself to alter what am doing to lessen the integrity of my product. That's number one.

The organic farmers also emphasized the need to produce healthy products as one of their motivations for engaging in organic farming. A middleaged, male, organic farmer from southern Ohio stated,

I have seen what hunger is in the world and not only do I wanna feed people but feed them correctly and in the right manner. Hunger could be in the form of poverty and in a rich sense, too, when people are just not eating the right way and in a familiar way.

Farmers' Communication Behaviors

The interviews revealed that differences existed in communication behaviors between organic and conventional farmers. The differences were categorized into the two subthemes: access to agricultural information, and communication with consumers.

\section{Access to Agricultural Information}

The conventional farmers who were interviewed indicated that as far as accessing agricultural information, they depended on their experience and knowledge that was passed to them by their parents and on print publications. For example, a middle-aged, male, conventional farmer from northern Ohio stated,

A lot has been learned just throughout the years. My father, just growing up around it and then publications, Obio Farm Journal, different kinds of magazines, not a lot of stuff online or the internet, kind of old school things, I guess so. When deciding planting depths, we read but you know most of these things is just a learned thing different people teach ya and you pay attention.
A majority of organic farmers mentioned conducting extensive research individually and consulting with other organic farmers before they made decisions on their farms. A middle-aged, male, aspiring, organic farmer from central Ohio stated,

We are in the route of looking at other farms and seeing how they grow and if they are similar to our interests then we'll go out and learn from them. But we also research our own. We read books and we look into the science of growing and try to take that route.

This was echoed by another middle-aged, male, organic farmer from southern Ohio who stated, "once again it goes back to the research, we are willing to read those 200-page books."

Another organic farmer who described himself as an upcoming entrepreneur stated, "I get many newspapers and magazines and articles and books at home that I obtain information."

\section{Communication with the Consumers}

Another key theme identified is that the organic and conventional farmers reported different communication behaviors with consumers. Conventional farmers discussed being busy and not having time to communicate with consumers, while the majority of organic farmers indicated being passionate about communicating with consumers. The following excerpts of an interview with one of the organic farmers from northern Ohio is an example of how organic farmers are reaching out to consumers:

We have a Facebook page obviously; we have an email and phone numbers that our customers have access to and then we've produced a smaller version of a pamphlet of what we have to offer and a short biography of our farm and what we have to offer and that's something that we can give to somebody. Even if they read it over just once we try to keep it to just have enough information for them to see what we have to offer in a compact package. We post our videos on YouTube and share short videos of what we do when people visit our farm. 
However, when one of the conventional farmers was asked about their involvement in communicating with consumers, their response indicated they were too busy working on the farm, and they did not have time to produce communication and outreach materials to reach consumers.

We are not very good at reaching out most of the times. We too busy. Got a lot of stuff to do and we are not, we don't measure our time in hours, we've more stuff to be done so we are doing it. Uh, unfortunately, we need to take more time to educate people but at this stage it's hard to educate people that are in such a busy lifestyle.

\section{Contributions of Differences in Communication} Behaviors among Organic and Conventional Farmers on Creation of Negative Perceptions about Agriculture The interviews revealed that the difference in perceptions about agriculture between farmers following different production practices may be contributing to negative perceptions about agriculture among the public. One of the conventional farmers from eastern Ohio, who also described himself as a communicator, stated,

The consumer is hard enough to please where it is. We want them to go direct to us with what they want. Are you sure you want grass or ... OK, that's what I want, and we are both working together, you pick what you like. Both are very humane, both done very healthy, both are this way or this. So, stop taking all the questions out for the consumer because we have so many write ups. And like I have said, not everybody that's writing that up is for the farmer. A lot of them are for different reasons and it could be to take away from the farmers so once consumers read that then it's start checking it out and well let's just eat vegetables that's all we are eating so the more we can stick together. As farmers, no matter if we are different on either side it will be, we will get a lot further because consumers do not want confusion.

However, most conventional farmers were quick to point out that the agricultural industry needs to reach out more to consumers with one voice. One of the middle-aged, male, conventional farmers stated,

It's opening up the farm gate, it's talking about how all food is raised and it's talking to them about the choices. So if you want to buy organic or if you wanna buy free range you know, you wanna buy something that's sugar free, fat free, or whatever, no matter what you are looking [for] we should be able to talk to you about what these food choices are and make sure that you understand what those food choices mean.

This was reiterated by another female conventional farmer from western Ohio:

How do you advocate through like your social media and stuff like that? I think that's an important . . . just because I feel like there is a lot of uneducated people in agriculture industry, you know. I think the media portrays things as sometimes farmers are bad or we slaughter and butcher animals and things like that. But, I mean, farmers are not bad people, we all eat, you know, you don't just go to the grocery store and buy your meat from Kroger, the meat came from somewhere, you know, so I think that's where there's a lot of miscommunication, and, you know, personally I've grown up with it so I know, you know, the way of the farmers and things like that. And I want to help educate, and so I wanna educate people about our farm and what we do. We sell our feeder cows and eventually they are gonna go to market, that's just what we do and it helps feed America. I want to get that out there to help people learn more. I think that there's a lot of missing education. I think there's a big opportunity there to kinda put that out there so if we can do anything on our side a little bit to help towards that goal then, you know, I wanna do our part, so.

While the conventional farmers focused on ensuring that they produce enough food to feed 
America, organic farmers emphasized the need for consumers to know how their food is produced and the impact that farming practices have on the quality of food produced and the environment. The organic farmers also indicated they were focused on informing consumers about the superiority of their produce, as indicated by one of the organic farmers from central Ohio, who stated,

Ag folks have masterminded their advertising and utilizing labels to give consumers feelgood feelings when I see a commercial. So, as a small 50-acre farmer competing against those corporate big guys, I have to compete against all those commercials, all those things you see walking through a grocery store and convince folks why I believe my product is more sustainable, healthier and so on.

This was also mentioned by another organic, middle-aged, male farmer, who described himself as being a part-time farmer and full-time teacher:

I think people are on a grand stand ... and I see this in my classroom as well, that people really don't think about what they are eating and it is a convenience factor. Can I have it right now? ... I understand that when prices go up people aren't happy. However, when health and quality of life can go up that might be a reasonable thing.

Furthermore, we observed that most of the organic farmers engaged with consumers as one way of getting markets for their products, as evidenced by the following quotes from organic farmers.

Am a direct sales farmer. I have consumers buy directly from me. I need to be able to, be able to converse with people who have zero exposure to agriculture, I have to make my customers come to me, I have to be able to communicate with my customers, otherwise they gonna go elsewhere for their product.

This was echoed by another farmer who indicated that they are active in communicating with the public because unlike conventional farmers, they work independently to sell their products.

So I have to compete against all those commercials, all those things you see walking through a grocery store and convince folks why I believe my product is more sustainable, healthier and so on while the big Tyson's, Purdue, uh, Monsantos, BRFS, seed companies to really have to compete against their pamphlets, their commercials, et cetera.

\section{Discussion}

The authors acknowledge that, given the scale of our study, the results of this exploratory study cannot be generalized to other populations of farmers in the U.S. Thus the discussion is limited to the results from the sampled participants and literature review. This paper is aimed at starting a conversation about other potential sources of negative perceptions about agriculture to inform research and practice.

The availability of multiple sources of agricultural information puts consumers at risk of being misinformed and developing negative perceptions about agriculture (Charanza \& Naile, 2012; Sellnow $\&$ Sellnow, 2014). In an attempt to address these challenges, agricultural communication experts have been producing various messages to counteract the negative perceptions, which has contributed to the use of agricultural communication as a public relations tool and has been criticized as being reactive instead of proactive (Kurtzo et al., 2016). Results of this study suggest that there are differences in farmers' communication behaviors with consumers based on their production practices. The differences in communication behaviors may be contributing to a presence of misinformation about agriculture, which has led to the creation of otherness among farmers. For example, in this study, all of the organic farmers introduced themselves as "organic farmers," while conventional farmers introduced themselves as "farmers" and focused on the commodity they produced.

The results of our study affirm that differences in farmers' beliefs and values may be responsible for differences in production practices (Thompson et al., 2015). From the interviews, we observed that 
most of the organic farmers were focused on ensuring that consumers know how their food is produced, unlike the conventional farmers, who were concerned about improving productivity. This is in line with a study conducted by Peterson, Barkley, Chacon-Cascante, and Kastens (2012), who reported that organic and younger farmers are motivated to engage in organic farming because of their interest in promoting quality of life and being good stewards of the environment. Since most of the_organic farmers consider themselves to be environmental stewards, they tend to be highly involved in civic engagement activities (Goldberger, 2011). As reported by Goldberger (2011), increased participation in civic engagement to educate the public as well as their involvement in direct marketing are some of the factors that influence organic farmers' communication behaviors with the consumers. However, apart from civic engagement, the results of this study indicate that organic farmers sell their produce directly to consumers, and so they use communication with consumers as a marketing tool.

The results also indicate that conventional farmers' motivations for engaging in farming seem to be influenced by the need to produce more food. Thus they do not value communicating with the public. This is likely because large farmers sell their products to co-ops or distributors, rather than directly to consumers. Therefore, they do not feel obligated to communicate with the public, which has likely contributed towards their limited engagement in communicating with the consumers. Conventional farmers in this study cited a lack of time as a reason why they did not communicate with consumers. However, the presence of social media platforms, such as YouTube and Facebook, provide opportunities for these farmers to share information through short videos of how they carry out different operations. Therefore, it is important for agricultural communicators to encourage conventional farmers to capture videos of their daily activities and share with the public, so the public is informed.

The results of the study also indicated that the differences in production practices have created some rivalry between organic and conventional farmers. For example, during the interviews it was clear some of the organic farmers considered themselves to be better stewards of the land, and that they paid special attention to ensure production of quality products, unlike conventional farmers. Even though this may not be true of all farmers, it was evident that farmers of differing production practices did not always see issues the same way. Such rivalries have distracted them from focusing on the one thing that unifies them: farming. In this study, organic farmers believed they were doing the right thing and their product was the best, while conventional farmers perceived organic farmers as inexperienced. Moreover, organic farmers seemed to be proactive in identifying different sources of agricultural information while communicating with each other and the public, unlike conventional farmers, who typically learned from generations before them. Organic farmers' proactiveness in communicating with the public, as well as the perceived benefits associated with the farming practice, may help explain the reasons for increased media coverage about the benefits of organic farming (Cleveland et al., 2015; Hughner et al., 2007). Furthermore, some organic farmers have been reported to be part of organic farming activist groups, which are proactive in delivering information about the benefits of organic farming to the consumer (Charanza \& Naile, 2012; Coombs, 2007).

The results from this study indicated that organic farmers were proactive in taking advantage of new and emerging media to communicate about their products. The presence of various communication media, including social media, serves as an opportunity for organic farmers to market their products and help them deliver messages that resonate with consumers. The results of this study are in line with what Agunga (1995) found: differences in farming practices have the potential to contribute toward differences in farmers' communication behaviors. However, most of the research conducted has placed a focus on the differences in farmers' information-seeking behaviors (Jacobson et al., 2003) and not their communication with each other and consumers. A number of studies conducted on agricultural communication have focused on identifying farmers' communication behaviors when accessing agri- 
cultural information (Chiu, et al., 2015; Duram \& Larson 2001; Egri, 1999; Niewolny \& Lillard, 2010). However, the results of this study indicate that organic farmers are not only seeking information, but also are communicating with consumers. There is need for more research on farmers' communication behaviors with consumers to identify the content of these messages and how they influence the audience's perceptions of agriculture.

\section{Conclusions}

Due to the small sample size, convenience sampling strategy, and use of qualitative research methods, the results from this study should not be generalized. Nevertheless, the results indicate that in our sample there are differences in communication behaviors between farmers involved in different farming practices. Even though the sample may be small, these results provide a basis for starting a conversation regarding the impact of the differences in farming practices on how the agricultural industry communicates with consumers. Furthermore, the fact that these differences were observed among farmers attending the same conference and sessions is telling because it speaks of the differences in the reasons for farmers' participation in conferences or sessions. Conflicting views were apparent among farmers who used different farming practices, and it is likely that these conflicts are influencing the information the public is receiving. Despite the challenge, farmers continue to focus on the media as a source of negative perceptions among consumers. However, though this may be true, it is important to understand the role played by differences in production practices as well as communication behaviors among farmers. There is need for more research to be conducted with different farmers who follow different production practices in order to examine thoroughly the impact of differences in production behaviors on creation of negative perceptions about agriculture. More research should also be conducted on how consumers access and process information received from farmers.

There is also need for more research aimed at identifying the factors that motivate farmers to engage in various communication behaviors. These studies should employ mixed methods that include a content analysis of the messages that farmers share with consumers in relation to demographic factors such as land size, education level, number of years involved in farming, and marketing strategies used. In the current study, demographic characteristics such as age, education status, and size of farm were not captured. It is recommended that future research be conducted using quantitative research methods to establish the impact of demographic and farm characteristics on farming practices as well as communication behaviors. Conducting such research will be useful in identifying factors that influence farmers' communication behaviors with consumers and will help identify the sources for the negative perceptions about agriculture.

Unlike in the past, where communication was used as a tool for relaying information to farmers, the current challenges and increased technological advancements in communication call for a way to better explore ways of improving communication among farmers as well as their ability to communicate with consumers. This necessitates the implementation of interventions and projects aimed at promoting collaboration and coordination among farmers who are involved in different production practices, so they speak with one voice and send a unified message to the public. Such interventions will be useful because in some cases the public is not aware of the differences between organic and conventional farming (Abrams et al., 2010; McFadden \& Huffman, 2017). It will be useful to establish standalone communication organizations and interventions aimed at providing platforms for dialogue between organic and conventional farmers to discuss the advantages and disadvantages of each farming practice. The platforms used could include podcasts, YouTube, and Facebook groups where organic and conventional farmers would be provided with an opportunity to interact with the public. The provision of fair and balanced information to the public that outlines the benefits and downsides of each production practice is crucial to ensure that the public makes informed decisions (Gottschalk \& Leistner, 2013). 


\section{References}

Abrams, K. M., Meyers, C. A., \& Irani, T. A. (2010). Naturally confused: Consumers' perceptions of all-natural and organic pork products. Agriculture and Human Values, 27, 365-374. https://doi.org/10.1007/s10460-009-9234-5

Agunga, R. A. (1995). What Ohio extension agents say about sustainable agriculture. Journal of Sustainable Agriculture, 5(3), 169-187. https://doi.org/10.1300/J064v05n03 13

Ajzen. I. (1985). From intentions to actions: A theory of planned behavior. In J. Kuhl \& J. Beckmann (Eds.), Action Control (pp. 11-39). Springer. https://doi.org/10.1007/978-3-642-69746-3 2

Ajzen, I. (1991). The theory of planned behavior. Journal of Organizational Behavior and Human Decision Processes, 50(2), 179_ 211. https://doi.org/10.1016/0749-5978(91)90020-T

Alexopoulos, G., Koutsouris, A., \& Tzouramani, I. (2010, July). Should I stay or should I go? Factors affecting farmers' decision to convert to organic farming as well as to abandon it. In 9th European IFS A Symposium, Vienna (Austria) (pp. 1083-1093).

Arbuckle Jr., J. G., Morton, L. W., \& Hobbs, J. (2015). Understanding farmer perspectives on climate change adaptation and mitigation: The roles of trust in sources of climate information, climate change beliefs, and perceived risk. Environment and Behavior, 47(2), 205-234. https://doi.org/10.1177/0013916513503832

Baker, L. M., Abrams, K., Irani, T., \& Meyers, C. (2011). Managing media relations: Determining the reputation of land grant institutions from the perspective of media professionals. Journal of Applied Communications, 95(2), 60-74. https://doi.org/10.4148/1051-0834.1180

Barton, G. A. (2018). The global history of organic farming. Oxford University Press. https://doi.org/10.1093/oso/9780199642533.001.0001

Bravo-Monroy, L., Potts, S. G., \& Tzanopoulos, J. (2016). Drivers influencing farmer decisions for adopting organic or conventional coffee management practices. Food Policy, 58, 49-61. https://doi.org/10.1016/j.foodpol.2015.11.003

Cahill, S., Morley, K., \& Powell, D. A. (2010). Coverage of organic agriculture in North American newspapers: Media: linking food safety, the environment, human health and organic agriculture. British Food Journal, 112(7), 710-721. https://doi.org/10.1108/00070701011058244

Chakraborty, U., \& Bhat, S. (2018). The effects of credible online reviews on brand equity dimensions and its [sic] consequence on consumer behavior. Journal of Promotion Management, 24(1), 57-82. https://doi.org/10.1080/10496491.2017.1346541.

Charanza, A. D., \& Naile, T. L. (2012). Media dependency during a food safety incident related to the U.S. beef industry. Journal of Applied Communications, 96(3), 38-50. https://doi.org/10.4148/1051-0834.1145

Chiu, S., Cheyney, M., Ramirez, M., \& Gerr, F. (2015). Where do agricultural producers get safety and health information? Journal of Agromedicine, 20(3), 265-272. https://doi.org/10.1080/1059924X.2015.1045156.

Cleveland, D. A., Carruth, A., \& Mazaroli, D. N. (2015). Operationalizing local food: Goals, actions, and indicators for alternative food systems. Agriculture and Human V alues, 32, 281-297. https://doi.org/10.1007/s10460-014-9556-9

Conner, M., \& Armitage, C. J. (1998). Extending the theory of planned behavior: A review and avenues for further research. Journal of Applied Social Psychology, 28(15), 1429-1464. https://doi.org/10.1111/j.1559-1816.1998.tb01685.x

Coombs, W. T. (2007). Attribution theory as a guide for post-crisis communication research. Public Relations Review, 33(2), 135-139. https://doi.org/10.1016/j.pubrev.2006.11.016

Couture, A. L., Zaidi, A. U., \& Maticka-Tyndale, E. (2012). Reflective accounts: An intersectional approach to exploring the fluidity of insider/outsider status and the researcher's impact on culturally sensitive post-positivist qualitative research. Qualitative Sociology Review, 8(1), 86-105. http://www.qualitativesociologyreview.org/ENG/volume21.php

Cranfield, J., Henson, S., \& Holliday, J. (2010). The motives, benefits, and problems of conversion to organic production. Agriculture and Human Values, 27, 291-306. https://doi.org/10.1007/s10460-009-9222-9

Da Cunha, D. T., Antunes, A. E. C., Da Rocha, J. G., Dutra, T. G., Manfrinato, C. V., Oliveira, J. M., \& Rostagno, M. A. (2019). Differences between organic and conventional leafy green vegetables perceived by university students: Vegetables attributes or attitudinal aspects? British Food Journal, 121(7), 1579-1591. https://doi.org/10.1108/BFJ-08-2018-0503

Dainton, M. (2010). Explaining theories of interpersonal communication. In M. Dainton, \& E. D. Zelley (Eds.), Applying communication theory to professional life (pp. 55-76). SAGE. 
Darnhofer, I., Schneeberger, W., \& Freyer, B. (2005). Converting or not converting to organic farming in Austria: Farmer types and their rationale. Agriculture and Human Values, 22, 39- 52. https://doi.org/10.1007/s10460-004-7229-9

Della Porta, D. (2008). Comparative analysis: Case-oriented versus variable-oriented research. In D. Della Porta \& M. Keating (Eds), Approaches to methodologies in the social sciences: A pluralist perspective (pp. 198-222). Cambridge University Press. https://doi.org/10.1017/CBO9780511801938.012

Duram, L. A., \& Larson, K. L. (2001). Agricultural research and alternative farmers' information needs. The Professional Geographer, 53(1), 84-96. https://doi.org/10.1080/00330124.2001.9628438

Dwyer, S. C., \& Buckle, J. L. (2009). The space between: On being an insider-outsider in qualitative research. International Journal of Qualitative Methods, 8(1), 54-63. https://doi.org/10.1177/160940690900800105

Egri, C. P. (1999). Attitudes, backgrounds and information preferences of Canadian organic and conventional farmers: Implications for organic farming advocacy and extension. Journal of Sustainable Agriculture, 13(3), 45-72. https://doi.org/10.1300/J064v13n03_05

Fatemi, A. H., \& Asghari, A. (2012). Attribution theory, personality traits, and gender differences among EFL learners. International Journal of Education, 4(2), 181-201. http://dx.doi.org/10.5296/ije.v4i2.1455.

Feldmann, C., \& Hamm, U. (2015). Consumers' perceptions and preferences for local food: A review. Food Quality and Preference, 40(A), 152-164. https://doi.org/10.1016/j.foodqual.2014.09.014

Flick, U. (2002). An introduction to qualitative research (2nd ed.). Sage.

Funk, M. J., \& McCombs, M. (2017). Strangers on a theoretical train: Inter-media agenda setting, community structure, and local news coverage. Journalism Studies, 18(7), 845-865. https://doi.org/10.1080/1461670X.2015.1099460

Galletta, A. (2003). Under one roof, through many doors: Understanding racial equality in an unequal world Unpublished doctoral dissertation]. City University of New York.

Gasson, R. (1973). Goals and values of farmers. Journal of Agricultural Economics, 24(3), 521-542. https://doi.org/10.1111/j.1477-9552.1973.tb00952.x

Goldberger, J. R. (2011). Conventionalization, civic engagement, and the sustainability of organic agriculture. Journal of Rural Studies, 27(3), 288-296. https://doi.org/10.1016/j.jrurstud.2011.03.002

Gottschalk, I., \& Leistner, T. (2013). Consumer reactions to the availability of organic food in discount supermarkets. International Journal of Consumer Studies, 37(2), 136-142. https://doi.org/10.1111/j.1470-6431.2012.01101.x

Harper, G. C., \& Makatouni, A. (2002). Consumer perception of organic food production and farm animal welfare. British Food Journal, 104(3/4/5), 287-299. https://doi.org/10.1108/00070700210425723

Harper, M., \& Cole, P. (2012). Member checking: Can benefits be gained similar to group therapy? The Qualitative Report, 17(2), 510-517. https://doi.org/10.46743/2160-3715/2012.2139

Harvey, L. (2015). Beyond member-checking: A dialogic approach to the research interview. International Journal of Research \& Method in Education, 38(1), 23-38. https://doi.org/10.1080/1743727X.2014.914487

Heider, F. (1958). The psychology of interpersonal relations. Wiley. https://doi.org/10.1037/10628-000

Hughner, R. S., McDonagh, P., Prothero, A., Shultz, C. J., \& Stanton, J. (2007). Who are organic food consumers? A compilation and review of why people purchase organic food. Journal of Consumer Behaviour, 6(2-3), 94-110. https://doi.org/10.1002/cb.210

Irani, T., \& Doerfert, D. L. (2013). Preparing for the next 150 years of agricultural communications. Journal of Applied Communications, 97(2), 6-13. https://doi.org/10.4148/1051-0834.1109

Jacobson, S. K., Sieving, K. E., Jones, G. A., \& Van Doorn, A. (2003). Assessment of farmer attitudes and behavioral intentions toward bird conservation on organic and conventional Florida farms. Conservation Biology, 17(2), 595-606. https://doi.org/10.1046/j.1523-1739.2003.01472.x

Kirchmann, H. (2019). Why organic farming is not the way forward. Outlook on Agriculture, 48(1), $22-27$. https://doi.org/10.1177/0030727019831702

Krystallis, A., \& Chryssohoidis, G. (2005). Consumers' willingness to pay for organic food: Factors that affect it and variation per organic product type. British Food Journal, 107(5), 320-343.

https://doi.org/10.1108/00070700510596901 
Kurtzo, F., Hansen, M. J., Rucker, K. J., \& Edgar, L. D. (2016). Agricultural communications: Perspectives from the experts. Journal of Applied Communications, 100(1), 17-28. https://doi.org/10.4148/1051-0834.1019

Laczniak, R. N., DeCarlo, T. E., \& Ramaswami, S. N. (2001). Consumers' responses to negative word-of-mouth communication: An attribution theory perspective. Journal of consumer Psychology, 11(1), 57-73. https://doi.org/10.1207/S15327663JCP1101 5

Legendre, S., \& Coderre, F. (2018). The impact of altruistic attribution and brand equity in food label campaigns. Journal of Product \& Brand Management, 27(6), 634-646. https://doi.org/10.1108/JPBM-12-2016-1381

Littlejohn, S. W., \& Foss, K. A. (2010). Theories of human communication (10 ${ }^{\text {th }}$ ed.). Waveland Press.

Marques, M. D., Critchley, C. R., \& Walshe, J. (2015). Attitudes to genetically modified food over time: How trust in organizations and the media cycle predict support. Public Understanding of Science, 24(5), 601-618. https://doi.org/10.1177/0963662514542372

Masambuka, F., Rodriguez, M., \& Buck, E. (2018, April). Drivers and shakers of agricultural communication: Implications for sustainable development in developing and developed countries [Paper presentation]. Association for International Agricultural and Extension Education 2018 Conference, Yucatan, Mexico.

Mase, A. S., \& Prokopy, L. S. (2014). Unrealized potential: A review of perceptions and use of weather and climate information in agricultural decision making. Weather, Climate, and Society, 6(1), 47-61. https://doi.org/10.1175/WCAS-D-12-00062.1

McCluskey, J. J., Kalaitzandonakes, N., \& Swinnen, J. (2016). Media coverage, public perceptions, and consumer behavior: Insights from new food technologies. Annual Review of Resource Economics, 8, 467-486. https://doi.org/10.1146/annurev-resource-100913-012630

McFadden, J. R., \& Huffman, W. E. (2017). Willingness-to-pay for natural, organic, and conventional foods: The effects of information and meaningful labels. Food Policy, 68, 214-232. https://doi.org/10.1016/i.foodpol.2017.02.007

McGuire, J., Morton, L. W., \& Cast, A. D. (2013). Reconstructing the good farmer identity: Shifts in farmer identities and farm management practices to improve water quality. Agriculture and Human Values, 30, 57-69. https://doi.org/10.1007/s10460-012-9381-y

McKendree, M. G. S., Croney, C. C., \& Widmar, N. J. O. (2014). Effects of demographic factors and information sources on United States consumer perceptions of animal welfare. Journal of Animal Science, 92(7), 3161-3173. https://doi.org/10.2527/jas.2014-6874

Meyers, C., Irlbeck, E., \& Fletcher, K. (2011). Postsecondary students' reactions to agricultural documentaries: A qualitative analysis. Journal of Applied Communications, 95(3), 82-95. https://doi.org/10.4148/1051-0834.1167

Mzoughi, N. (2011). Farmers' adoption of integrated crop protection and organic farming: Do moral and social concerns matter? Ecological Economics, 70(8), 1536-1545. https://doi.org/10.1016/j.ecolecon.2011.03.016

Nadricka, K., Millet, K., \& Verlegh, P. W. J. (2020). When organic products are tasty: Taste inferences from an Organic $=$ Healthy Association. Food Quality and Preference, 83, Article 103896. https://doi.org/10.1016/j.foodqual.2020.103896

Niewolny, K. L., \& Lillard, P. T. (2010). Expanding the boundaries of beginning farmer training and program development: A review of contemporary initiatives to cultivate a new generation of American farmers. Journal of Agriculture, Food Systems, and Community Development, 1(1), 65-88. https://doi.org/10.5304/jafscd.2010.011.010

ÖhlméYr, B., Olson, K., \& Brehmer, B. (1998). Understanding farmers' decision making processes and improving managerial assistance. Agricultural Economics, 18(3), 273-290. https://doi.org/10.1111/j.1574-0862.1998.tb00505.x

Patel, R. (2013). The long green revolution. The Journal of Peasant Studies, 40(1), 1-63. https://doi.org/10.1080/03066150.2012.719224.

Paul, M., Primrose, K., \& Chrispen, C. (2013). Learner support services in ODL: Using mobile technology as support service for the invisible student. World Journal of Management and Behavioural Studies, 1(2), 53-59. https://idosi.org/wjmbs/online.htm 
Peterson, H. H., Barkley, A. P., Chacón-Cascante, A., \& Kastens, T. L. (2012). The motivation for organic grain farming in the United States: Profits, lifestyle, or the environment? Journal of Agricultural and Applied Economics, 44(2), 137155. https://doi.org/10.1017/S1074070800000237

Prokopy, L. S., Bartels, W.-L., Burniske, G., \& Power, R. (2017). Agricultural extension and climate change communication. In Oxford Research Encyclopedia of Climate Science. https://doi.org/10.1093/acrefore/9780190228620.013.429

Ragin, C. C., \& Schneider, G. A. (2011). Case-oriented theory building and theory testing. In C. C. Ragin \& G. A. Schneider (Eds.), The SAGE Handbook of Innovation in Social Research Methods (pp. 151- 165). SAGE. https://doi.org/10.4135/9781446268261.n11

Sellnow, D. D., \& Sellnow, T. L. (2014). The challenge of exemplification in crisis communication. Journal of Applied Communications, 98(2), 53-64. https://doi.org/10.4148/1051-0834.1077

Seufert, V., Ramankutty, N., \& Mayerhofer, T. (2017). What is this thing called organic?_-How organic farming is codified in regulations. Food Policy, 68, 10-20. https://doi.org/10.1016/j.foodpol.2016.12.009

Specht, A. R., \& Beam, B. W. (2015). Prince Farming takes a wife: Exploring the use of agricultural imagery and stereotypes on ABC's The Bachelor. Journal of Applied Communications, 99(4), 20-33. https://doi.org/10.4148/1051-0834.1055

Spooner, J. M., Schuppli, C. A., \& Fraser, D. (2014). Attitudes of Canadian citizens toward farm animal welfare: A qualitative study. Livestock Science, 163, 150-158. https://doi.org/10.1016/j.livsci.2014.02.011

Stone, G., Singletary, M. \& Richmond, V. (1999). Clarifying communication theories: A hands on approach. WileyBlackwell.

Tewksbury, R. (2013). Qualitative versus quantitative methods: Understanding why qualitative methods are superior for criminology and criminal justice. Journal of Theoretical and Philosophical Criminology, 1(1), 38-58.

http://www.jtpcrim.org/archives.htm

Thompson, A. W., Reimer, A., \& Prokopy, L. S. (2015). Farmers' views of the environment: The influence of competing attitude frames on landscape conservation efforts. Agriculture and Human V alues, 32, 385-399. https://doi.org/10.1007/s10460-014-9555-x

Torjusen, H., Lieblein, G., Wandel, M., \& Francis, C. A. (2001). Food system orientation and quality perception among consumers and producers of organic food in Hedmark County, Norway. Food Quality and Preference, 12(3), $207-216$. https://doi.org/10.1016/S0950-3293(00)00047-1

U.S. Department of Agriculture [USDA]. (2015a). USD A Coexistence fact sheets: Organic farming [Fact sheet]. USDA Office of Communications. https://www.usda.gov/sites/default/files/documents/coexistence-organic-farming-factsheet.pdf

USDA. (2015b). USD A Coexistence fact sheets: Conventional farming [Fact sheet]. USDA Office of Communications. https://www.usda.gov/sites/default/files/documents/coexistence-conventional-farming-factsheet.pdf

Urquhart, C. (2013). Grounded theory for qualitative research: A practical guide. SAGE. https://doi.org/10.4135/9781526402196

Valli, L., \& Buese, D. (2007). The changing roles of teachers in an era of high-stakes accountability. American Educational Research Journal, 44(3), 519-558. https://doi.org/10.3102/0002831207306859

Varble, S., Secchi, S., \& Druschke, C. G. (2016). An examination of growing trends in land tenure and conservation practice adoption: Results from a farmer survey in Iowa. Environmental Management, 57, 318-330. https://doi.org/10.1007/s00267-015-0619-5

Weiner, B. (1986). An attributional theory of motivation and emotion. Springer-Verlag. https://doi.org/10.1007/978-1-4612-4948-1

Xie, B., Wang, L., Yang, H., Wang, Y., \& Zhang, M. (2015). Consumer perceptions and attitudes of organic food products in Eastern China. British Food Journal, 117(3), 1105-1121. https://doi.org/10.1108/BFJ-09-2013-0255 